\title{
Differentiation of plant derived organic matter in soil, loess and rhizoliths based on $\boldsymbol{n}$-alkane molecular proxies
}

\author{
Martina Gocke • Yakov Kuzyakov • \\ Guido L. B. Wiesenberg
}

Received: 12 February 2011/ Accepted: 16 September 2011

(C) Springer Science+Business Media B.V. 2011

\begin{abstract}
Organic matter (OM) in loess-paleosol sequences is used for paleoenvironmental reconstructions, based e.g. on stable carbon isotope composition. Loess OM (LOM) is assumed to derive from synsedimentary vegetation, i.e. predominantly grass. However, low organic $\mathrm{C}$ contents make LOM prone to postsedimentary contamination. It was the aim of this study to reveal (1) whether OM of the loess sequence at Nussloch (SW Germany) was altered by postsedimentary input, (2) to which depth, and (3) from which source vegetation this younger OM derives. Therefore, the alkane composition of LOM was compared to that of potential source OM for postsedimentary contamination: recent soil, vegetation growing on the loess sequence, calcified roots (rhizoliths) which derive from postsedimentary deep-rooting plants but not from recent vegetation, and loess in direct vicinity of these former roots. Alkane molecular proxies including carbon preference index and average chain length revealed that grass biomass was the source of soil and LOM. The latter was, except for the uppermost $0.6 \mathrm{~m}$ of loess, not affected by pedogenic processes. Further,
\end{abstract}

M. Gocke $(\bowtie) \cdot$ G. L. B. Wiesenberg

Department of Agroecosystem Research, BayCEER, University of Bayreuth, 95447 Bayreuth, Germany

e-mail: martina.gocke@uni-bayreuth.de

Y. Kuzyakov

Department of Soil Science of Temperate and Boreal Ecosystems, University of Göttingen, 37077 Göttingen, Germany recent vegetation did not contribute to $\mathrm{OM}$ within and loess adjacent to rhizoliths, which were formed under native tree and/or shrub vegetation prior to agricultural use. Strongest degradation of LOM and large amounts of microbial derived OM were found in rhizoloess, indicating former rhizosphere processes. Molecular proxies indicate that overprinting of LOM even in loess distant to former roots cannot be excluded. Therefore, paleoenvironmental reconstructions based on loess $\delta^{13} \mathrm{C}_{\text {org }}$ should be regarded with caution.

Keywords Roots - Organic matter .

Carbon preference index - Average chain length .

Source apportionment

\section{Introduction}

Loess-paleosol sequences are considered as important terrestrial archives for studying Quaternary climate (Pye and Sherwin 1999). In these sequences, proxies including stable carbon isotope composition $\left(\delta^{13} \mathrm{C}\right)$ of organic matter (OM) are frequently used for chronological investigations and reconstruction of former vegetation $\left(\mathrm{C}_{3}\right.$ or $\mathrm{C}_{4}$ vegetation and shift between those; Wang et al. 1997), precipitation (e.g. response of $\mathrm{C}_{3}$ vegetation to humidity/aridity shift; Hatté et al. 1999; Hatté and Guiot 2005) or atmospheric $\mathrm{CO}_{2}$ concentrations (Hatté et al. 1998). One obstacle of these studies, however, is the low organic carbon 
$\left(\mathrm{C}_{\text {org }}\right)$ content of typical loess which usually does not exceed $\sim 2 \mathrm{mg} \mathrm{g}^{-1}$ (Antoine et al. 2009; Galović et al. 2009; Liu et al. 2007). Commonly it is assumed that loess OM (LOM) exclusively derived from aboveground biomass of those plants that prevailed during loess accumulation (e.g. Zhou et al. 2005). As loess was sedimented during cold periods, the source vegetation of LOM was mainly grass, partially associated with dwarf shrubs or trees (Liu et al. 1996; Bai et al. 2009). It is still under debate, if trees were growing in the areas of loess accumulation, or if the tree derived OM, which is now observed in loess (e.g. pollen, biomarkers including lipidic compounds), was incorporated together with dust. However, low $\mathrm{C}_{\text {org }}$ contents easily enable masking of synsedimentary LOM by OM that may be incorporated postsedimentary. Such contamination can be associated with OM from dust source areas (Liu et al. 2007), OM from distant untypical source area (Pye 1995), OM from Sahara dust (Stahr and Herrmann 1996), from recent agriculture/pedogenesis (Head et al. 1989) or root derived carbon from postsedimentary deep-rooting shrubs or trees (Gocke et al. 2010a). This can lead to misinterpretation of paleoenvironmental information. The amount of incorporated OM other than the synsedimentary incorporated OM usually cannot be assessed by color change or other properties of loess, e.g. a change in $\mathrm{C}_{\text {org }}$ contents or $\delta^{13} \mathrm{C}_{\text {org }}$ (Gocke et al. 2010a).

If roots or root parts originating from postsedimentary penetrating plants are calcified, leading to formation of rhizoliths or calcified root cells (Klappa 1980; Becze-Deák et al. 1997; Pustovoytov and Terhorst 2004), carbonatic tubes remain in loess. This carbonatic encrustation of roots, probably generated during short periods of few years to decades (Gocke et al. 2010b), might entail conservation of the former root tissue as well as preservation of rhizodeposits released during the root's lifetime. Therefore, rhizoliths as well as surrounding loess are suitable to estimate amounts of root derived $\mathrm{C}$ incorporated in loess. Former studies focusing on rhizoliths revealed that rhizoliths are likely attributed to roots of tree or shrub vegetation (e.g. Ziehen 1980; Wright et al. 1988). This was recently confirmed by the investigation of lipid molecular proxies (Gocke et al. 2010a). The fact that source vegetation of rhizoliths was different than that of surrounding loess with respect to functional plant groups (grass vs. shrub/tree) and plant part (root vs. shoot; Gocke et al. 2010a) reinforced the possibility of postsedimentary formation of rhizoliths. Furthermore, it was shown that in the vicinity of the former root, which was part of the former rhizosphere, a substantial part of LOM can be attributed to root derived C (Gocke et al. 2010a).

Lipids and especially alkanes are comparatively stable organic compounds compared e.g. to functionalized lipids, unsaturated lipids (Zhou et al. 2005) including fatty acids (Wiesenberg et al. 2004) or sugars (Marschner et al. 2008). As such alkanes have been frequently used in paleoenvironmental studies for source apportionment of OM in terrestrial archives including lake sediments (Schwark et al. 2002), peat sequences (Zhou et al. 2005) and loess sequences (Xie et al. 2003, 2004; Zech et al. 2009). In these archives especially long chain $n$-alkanes with a chain length of 25-33 carbons and with a strong predominance of odd numbered homologues derived from epicuticular waxes of higher plant biomass (Eglinton et al. 1962; Kolattukudy et al. 1976). In contrast to these compounds, short and mid chain homologues $\left(<\mathrm{C}_{25}\right)$ derived from multiple sources including higher plant biomass (Kuhn et al. 2010), microbial biomass (Kolattukudy et al. 1976), or degradation products, e.g. biomass burning (Wiesenberg et al. 2009). Among long chain alkanes several molecular proxies were established to assess different origins of biomass (Schwark et al. 2002) or degradation of biogenic compounds (Zech et al. 2009; Buggle et al. 2010). The relative contribution of $\mathrm{C}_{27}, \mathrm{C}_{29}, \mathrm{C}_{31}$ and $\mathrm{C}_{33} n$ alkanes allows for a rough estimation of tree derived biomass, which can be strongly enriched in $n-\mathrm{C}_{27}$ (Schwark et al. 2002), whereas grass biomass is commonly characterized by an enrichment of $n-\mathrm{C}_{31}$ and $n-C_{33}$ (Maffei 1996a, b; Schwark et al. 2002; Wiesenberg et al. 2004). Therefore, the ratio of $C_{27} /$ $\mathrm{C}_{31} n$-alkanes has been frequently used in terrestrial sedimentary sequences to distinguish between $\mathrm{OM}$ deriving mainly from tree (high values) or grass vegetation (low values). However, there are numerous plant species, where $n-C_{29}$ is the most abundant alkane. Such alkane composition does not allow apportionment of trees or grasses as most abundant plant source (e.g. Maffei 1996b, Sachse et al. 2006). Therefore, complementary investigations like e.g. pollen, phytoliths or malacological studies are required to determine the source of alkanes, where the pattern does not show a clear predominance of tree 
or grass derived components. Furthermore, several parameters were established to assess the source biomass and degree of degradation including the average chain length (ACL) of alkanes and the carbon preference index (CPI, or odd over even predominance, OEP). These enable tracing of degradation of $\mathrm{OM}$ in terrestrial sedimentary sequences, even though it remains still difficult to reconstruct the amount and quality of the biomass incorporated during sedimentation. In addition to the determination of sources and degradation, lipids including alkanes were recently used to assess postsedimentary modification of sedimentary OM, which was related to rooting of plants and reflected in rhizoliths and surrounding loess in the Nussloch profile (Gocke et al. 2010a).

The aim of the present study was to investigate the origin of the overprinting of synsedimentary LOM. We hypothesized that younger biomass is attributed mainly to root derived OM from postsedimentary penetrating plants. By use of different lipid molecular proxies, rhizolith $\mathrm{OM}$ was outlined from other potential sources of OM, i.e. recent soil OM (SOM) and biomass of recent vegetation. The late Pleistocene loess sequence of Nussloch (SW Germany) with a maximum thickness of $13 \mathrm{~m}$ was sampled in the uppermost $7 \mathrm{~m}$ for rhizoliths and loess which was free of visible root remains. Pairs of rhizoliths and loess from identical depth intervals were compared for their organic carbon $\left(\mathrm{C}_{\text {org }}\right)$ content and lipid composition. Additionally, these samples were compared to recent soil horizons and the most abundant vegetation whilst sampling. The Nussloch site was intensively studied during the past decades at profiles close to the recent study site: standard profiles P2-P4 (see Antoine et al. 2009 and references therein). Numerous approaches for paleoenvironmental reconstruction were applied including different dating methods like ${ }^{14} \mathrm{C}$-AMS (Lang et al. 2003) and optically stimulated luminescence (OSL) dating (Lang et al. 2003), $\delta^{13} \mathrm{C}_{\text {org }}$ to assess paleoprecipitation (Hatté and Guiot 2005) as well as grain size and geochemical analysis to obtain information on source of loess deposits (Porter and An 1995; Rousseau et al. 2007; Machalett et al. 2008). Molecular proxies were scarcely investigated (Gocke et al. 2010a), although it was observed for the Nussloch site that postsedimentary impregnation of LOM is possible due to the abundant rhizoliths (up to $\sim 190$ rhizoliths $\mathrm{m}^{-2}$; Wiesenberg and Gocke, unpublished data). To improve understanding of $\mathrm{OM}$ in this profile and to determine whether the LOM reflects original or postsedimentary OM, we assessed the sources of loess and rhizolith $\mathrm{OM}$ via molecular proxies for the upper part ( $0-7 \mathrm{~m})$ of the profile, where rhizoliths are highly abundant.

\section{Materials and methods}

Study site

The study site is situated in a quarry at the eastern side of the Upper Rhine valley $\left(49^{\circ} 18.724^{\prime} \mathrm{N}, 8^{\circ} 43.381^{\prime} \mathrm{E}\right.$, $217 \mathrm{~m}$ a.s.1.), about $10 \mathrm{~km}$ south of Heidelberg near the village Nussloch. There the loess-paleosol sequence of late Pleistocene age covers more than $13 \mathrm{~m}$ depth and represents mainly the last interglacial/ glacial cycle, which has been intensively studied especially in the standard profiles P2-P4 (e.g. Zöller et al. 1988; Antoine et al. 2001, 2009). At the top of the profile, the recent soil is developed as $0.6 \mathrm{~m}$ thick Vertic Cambisol Calcaric Siltic (FAO 2006) with $A_{p}$, $\mathrm{B}_{\mathrm{w} 1}, \mathrm{~B}_{\mathrm{w} 2}$ and $\mathrm{C}$ horizons (Fig. 1a), whereas agricultural use ended 3 years before sampling due to the expansion of the quarry. Therefore, the present vegetation, which was collected during the sampling campaign in October 2009, consisted of grasses, herbs and small shrubs. Due to the former agricultural use, the sampled plant species were most likely not the dominant plants contributing to soil formation during the past decades or centuries. However, due to lack of knowledge of the dominant plants during soil formation, the actual vegetation was sampled to correlate recent plant input, former agricultural use and sedimentary LOM. The historical use of this site is not known, except for agricultural use with annual ploughing during the past decades.

Within the quarry the standard profiles P2, P3 and $\mathrm{P} 4$ are considered as a type sequence for Western Europe (Antoine et al. 2001, 2009). Samples were taken in the southwestern part of the quarry of the HeidelbergCement AG at a distance of $400 \mathrm{~m}$ WSW from the standard profile P4 from Antoine et al. (2001). The new profile has a thickness of more than $13 \mathrm{~m}$ and covers sediments and incipient soils mainly of the Upper Pleniglacial. Rhizoliths were abundant from $0.8 \mathrm{~m}$ below the present surface down to a depth of at least $9 \mathrm{~m}$ (Gocke et al. 2011). These were largely abundant until $6.9 \mathrm{~m}$ depth. They typically have 

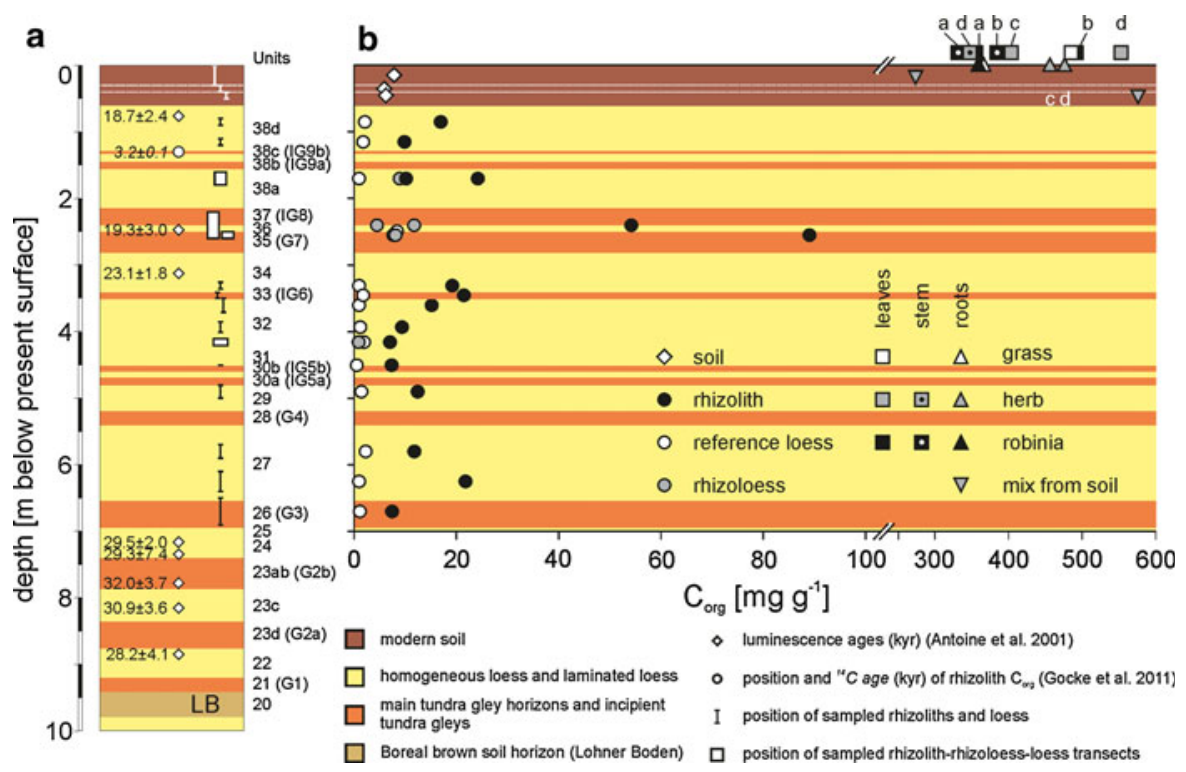

Fig. 1 a Upper Pleniglacial and Holocene part of the Nussloch profile, redrawn after Antoine et al. (2009). Stratigraphical units after Rousseau et al. (2007) and Antoine et al. (2009). Luminescence ages (with approximate depths) are taken from the standard profile P4 (Antoine et al. 2009) which is located approximately $400 \mathrm{~m}$ from the profile sampled in the present study. The correlation of the stratigraphical units between both profiles permits transmission of the luminescence ages.

various diameters between few $\mathrm{mm}$ to $\sim 3 \mathrm{~cm}$ and can be traced over depth intervals of several $\mathrm{dm}$ up to ca. $1.5 \mathrm{~m}$.

According to literature (Lang et al. 2003), $\mathrm{CaCO}_{3}$ contents of the Nussloch section vary between $0 \mathrm{mg} \mathrm{g}^{-1}$ in the last interglacial Bt horizon and $>300 \mathrm{mg} \mathrm{g}^{-1}$ in the loess sediments. In contrast, organic carbon $\left(\mathrm{C}_{\text {org }}\right)$ contents are very low and reach values $\geq 3 \mathrm{mg} \mathrm{g}^{-1}$ only in paleosols (Hatté et al. 1998; Lang et al. 2003).

\section{Sampling}

For comparison and differentiation between various sources of OM in soil and loess, sampling covered the upper $6.9 \mathrm{~m}$ of the profile, including a substantial part of the Upper Pleniglacial loess sequence (UPG) and the recent soil. One representative sample from each horizon of the soil ( $\sim 200 \mathrm{~g})$ was taken at three points with a distance of $>1 \mathrm{~m}$ to each other and combined thereafter. Roots were recovered from the $A_{p}$ and $B_{w 2}$ horizons during sieving, which could not be attributed to a single plant species and represent a mixture of
Positions of sampled soil, rhizoliths and loess are indicated by bars, those of rhizolith-rhizoloess-loess transects by boxes. b $\mathrm{C}_{\text {org }}$ contents of recent plant biomass, as well as soil, loess and rhizoliths depending on depth in the profile. Dotted lines in soil indicate depth of individual soil horizons $\left(\mathrm{A}_{\mathrm{p}}, \mathrm{B}_{\mathrm{w} 1}\right.$ and $\left.\mathrm{B}_{\mathrm{w} 2}\right)$. Note different scale of $\mathrm{C}_{\text {org }}$ axis for rhizolith, soil and loess compared to recent plant biomass ( $a, b=$ replicate plants of $R$. pseudoacacia, $c=T$. maritimum indorum, $d=S$. canadensis)

roots from various plants. Further, rhizolith samples were taken at depths between 0.8 and $6.9 \mathrm{~m}$ (Table 1). As rhizoliths occurred with lengths of up to several $\mathrm{dm}$, samples represent depth intervals between few $\mathrm{cm}$ and $40 \mathrm{~cm}$ (Fig. 1a). Due to their different size, individual rhizolith samples comprised 2-50 g dry weight. In addition to each rhizolith, reference loess (>300 g) was sampled at the same depth interval, i.e. material which was free of visible root remains at a distance of $50-70 \mathrm{~cm}$ from the nearest visible root remain. Additionally, rhizosphere loess, i.e. material adjacent to the rhizoliths up to a distance of max. $5 \mathrm{~cm}$, was sampled (>50 g) for four depth intervals (Table 1). For these rhizosphere loess samples contribution of root versus loess derived OM was assessed.

As representative species for the recent vegetation, specimens of above- and belowground biomass were sampled from Italian Ryegrass (Lolium multiflorum [Lam.]), Scentless Mayweed (Tripleurospermum maritimum indorum [L.]), Canada Goldenrod (Solidago canadensis [L.]) and robinia (Robinia pseudoacacia [L.]; Table 2), the former being a typical indicator for 
Table 1 TLE normalized to sample weight and $\mathrm{C}_{\text {org }}$

\begin{tabular}{|c|c|c|c|c|c|c|c|}
\hline Sample type & Depth & $\operatorname{TLE}\left(\mu \mathrm{g} \mathrm{g}^{-1}\right)$ & $\operatorname{TLE}\left(\mathrm{mg} \mathrm{g}^{-1} \mathrm{C}_{\mathrm{org}}\right)$ & $n$-alkanes $\left(\mu \mathrm{g} \mathrm{g}^{-1} \mathrm{C}_{\text {org }}\right)$ & CPI & $\mathrm{ACL}_{\mathrm{lc}}$ & $\mathrm{ACL}_{\text {total }}$ \\
\hline \multicolumn{8}{|l|}{ Soil horizons } \\
\hline$A_{p}$ & $0-0.3$ & 276 & 35 & 267 & 11.0 & 29.6 & 26.4 \\
\hline $\mathrm{B}_{\mathrm{w} 1}$ & $0.3-0.4$ & 185 & 31 & 301 & 7.6 & 29.5 & 24.8 \\
\hline $\mathrm{B}_{\mathrm{w} 2}$ & $0.4-0.5$ & 103 & 17 & 204 & 6.2 & 29.3 & 24.3 \\
\hline \multicolumn{8}{|c|}{ Loess and rhizoliths } \\
\hline $\mathrm{R}$ & $0.8-0.9$ & 190 & 12 & 247 & 0.6 & 28.2 & 20.7 \\
\hline $\mathrm{L}$ & & 57 & 27 & 552 & 4.2 & 29.2 & 21.6 \\
\hline $\mathrm{R}$ & $1.1-1.2$ & 389 & 40 & 640 & 0.8 & 27.9 & 19.4 \\
\hline $\mathrm{L}$ & & 70 & 39 & 921 & 7.5 & 29.6 & 24.1 \\
\hline $\mathrm{R}$ & $1.6-1.8$ & 629 & 26 & 129 & 0.9 & 28.9 & 23.2 \\
\hline $\mathrm{R}$ & & 122 & 12 & 230 & 5.7 & 29.8 & 26.0 \\
\hline $\mathrm{RL}(0-1 \mathrm{~cm})$ & & 123 & 14 & 180 & 8.7 & 29.7 & 26.1 \\
\hline $\mathrm{L}$ & & 84 & 84 & 1,825 & 10.0 & 30.2 & 26.1 \\
\hline $\mathrm{R}$ & $2.2-2.6$ & 142 & 3 & 8 & 6.6 & 29.0 & 26.6 \\
\hline $\mathrm{RL}(0-2.5 \mathrm{~cm})$ & & 47 & 4 & 1,886 & 5.2 & 29.0 & 25.9 \\
\hline $\operatorname{RL}(2.5-5 \mathrm{~cm})$ & & 59 & 13 & 3,142 & 5.1 & 28.9 & 24.0 \\
\hline $\mathrm{L}$ & & 34 & 4 & 4,419 & 11.6 & 30.1 & 27.4 \\
\hline $\mathrm{R}$ & $2.5-2.6$ & 194 & 2 & 12 & 11.5 & 30.2 & 26.8 \\
\hline $\operatorname{RL}(0-2.5 \mathrm{~cm})$ & & 78 & 10 & 4,020 & 3.2 & 29.4 & 24.5 \\
\hline $\operatorname{RL}(2.5-5 \mathrm{~cm})$ & & 66 & 9 & 2,108 & 7.1 & 30.3 & 27.6 \\
\hline $\mathrm{R}$ & $3.25-3.35$ & 144 & 8 & 91 & 0.6 & 28.8 & 24.7 \\
\hline $\mathrm{L}$ & & 57 & 48 & 745 & 10.7 & 29.9 & 19.2 \\
\hline $\mathrm{R}$ & $3.4-3.5$ & 161 & 8 & 440 & 0.9 & 28.1 & 19.7 \\
\hline $\mathrm{L}$ & & 50 & 29 & 822 & 6.8 & 29.5 & 23.8 \\
\hline $\mathrm{R}$ & $3.5-3.7$ & 145 & 10 & 2 & 1.3 & 29.9 & 28.5 \\
\hline $\mathrm{L}$ & & 29 & 19 & 285 & 15.3 & 28.9 & 23.2 \\
\hline $\mathrm{R}$ & $3.85-4.0$ & 155 & 17 & 1,112 & 1.0 & 28.8 & 23.1 \\
\hline $\mathrm{L}$ & & 79 & 66 & 266 & 14.1 & 29.4 & 20.5 \\
\hline $\mathrm{R}$ & $4.1-4.2$ & 155 & 22 & 291 & 4.2 & 29.8 & 26.3 \\
\hline $\mathrm{RL}(0-1 \mathrm{~cm})$ & & 110 & 119 & 2,847 & 7.8 & 29.4 & 26.4 \\
\hline $\mathrm{L}$ & & 49 & 26 & 1,091 & 12.2 & 30.0 & 28.1 \\
\hline $\mathrm{R}$ & 4.5 & 68 & 9 & 414 & 0.8 & 29.1 & 21.4 \\
\hline $\mathrm{L}$ & & 56 & 107 & 1,174 & 7.2 & 28.9 & 22.0 \\
\hline $\mathrm{R}$ & $4.6-4.8$ & 86 & 7 & 54 & 2.0 & 29.1 & 24.4 \\
\hline $\mathrm{L}$ & & 45 & 30 & 368 & 9.9 & 29.8 & 25.0 \\
\hline $\mathrm{R}$ & $5.7-5.9$ & 96 & 8 & 269 & 1.1 & 28.2 & 20.7 \\
\hline $\mathrm{L}$ & & 47 & 21 & 457 & 9.0 & 28.8 & 26.3 \\
\hline $\mathrm{R}$ & $6.1-6.4$ & 190 & 9 & 197 & 0.9 & 28.6 & 21.1 \\
\hline $\mathrm{L}$ & & 23 & 20 & 276 & 8.3 & 29.7 & 21.2 \\
\hline $\mathrm{R}$ & $6.5-6.9$ & 197 & 26 & 36 & 2.3 & 29.2 & 27.1 \\
\hline $\mathrm{L}$ & & 100 & 88 & 2,125 & 4.3 & 28.9 & 22.5 \\
\hline
\end{tabular}

$C P I$ carbon preference index; $A C L_{l c}$ ACL of long chain $n$-alkanes; $A C L_{\text {total }}$ ACL of total $n$-alkanes of individual soil horizons and rhizolith-loess pairs from different depth intervals ( $R$ rhizolith, $L$ loess, $R L$ rhizoloess). For rhizoloess, numbers in parentheses indicate the distance from the rhizolith surface 
Table 2 TLE normalized to sample weight and $\mathrm{C}_{\text {org }}$

\begin{tabular}{|c|c|c|c|c|c|c|}
\hline Sample type & TLE $\left(\mu \mathrm{g} \mathrm{g}^{-1}\right)$ & $\operatorname{TLE}\left(\mathrm{mg} \mathrm{g}^{-1} \mathrm{C}_{\mathrm{org}}\right)$ & $n$-Alkanes $\left(\mu \mathrm{g} \mathrm{g}^{-1} \mathrm{C}_{\text {org }}\right)$ & CPI & $\mathrm{ACL}_{\mathrm{lc}}$ & $\mathrm{ACL}_{\text {total }}$ \\
\hline \multicolumn{7}{|l|}{ Aboveground biomass } \\
\hline L. multiflorum & 29,251 & 60 & 872 & 16.1 & 30.2 & 30.2 \\
\hline T. maritimum indorum & 8,398 & 21 & 118 & 2.0 & 28.7 & 28.4 \\
\hline S. canadensis (leaves) & 55,389 & 100 & 150 & 5.3 & 29.9 & 29.5 \\
\hline \multirow[t]{2}{*}{ S. canadensis (stem) } & 20,393 & 59 & 76 & 2.5 & 29.0 & 28.4 \\
\hline & 10,307 & 30 & 84 & 1.5 & 28.8 & 28.6 \\
\hline \multirow[t]{2}{*}{ R. pseudoacacia (leaves) } & 76,382 & 215 & 875 & 15.9 & 27.2 & 26.9 \\
\hline & 43,193 & 88 & 636 & 13.7 & 27.7 & 27.5 \\
\hline \multirow[t]{3}{*}{ R. pseudoacacia (stem) } & 24,864 & 75 & 98 & 18.8 & 28.2 & 28.0 \\
\hline & 23,824 & 72 & 198 & 3.0 & 28.4 & 28.2 \\
\hline & 27,957 & 73 & 250 & 13.5 & 28.2 & 28.1 \\
\hline \multicolumn{7}{|l|}{ Roots } \\
\hline L. multiflorum & 9,619 & 26 & 90 & 1.9 & 29.0 & 27.9 \\
\hline T. maritimum indorum & 20,777 & 46 & 144 & 1.3 & 29.0 & 28.1 \\
\hline S. canadensis & 39,959 & 84 & 18 & 6.0 & 29.5 & 28.5 \\
\hline \multirow[t]{2}{*}{ R. pseudoacacia } & 15,785 & 44 & 9 & 1.5 & 29.0 & 28.0 \\
\hline & 18,196 & 51 & 8 & 1.6 & 28.7 & 23.0 \\
\hline Root mixture, $A_{p}$ & 1,418 & 5 & 98 & 2.4 & 28.5 & 27.1 \\
\hline Root mixture, $\mathrm{B}_{\mathrm{w} 2}$ & 7,589 & 13 & 49 & 5.8 & 28.9 & 27.9 \\
\hline
\end{tabular}

$C P I$ carbon preference index; $A C L_{l c}$ ACL of long chain $n$-alkanes; $A C L_{\text {total }}$ ACL of total $n$-alkanes of grass (L. multiflorum); herbs (T. maritimum indorum, $S$. canadensis) and robinia (R. pseudoacacia), as well as of roots recovered from soil horizons

disturbed ecosystems like e.g. acre margins or embankments (R. Stahlmann, pers. comm.).

After sampling, all material was immediately ovendried at $\leq 60^{\circ} \mathrm{C}$. Soil samples were dry sieved at $2 \mathrm{~mm}$ to separate roots. For $S$. canadensis and R. pseudoacacia aboveground biomass was separated into stem and leaves. Rhizosphere loess was scratched from rhizoliths using a brush. Afterwards, samples were ground in a ball mill (MM200, Retsch, Germany) and homogenized. Grinding of loess samples in a ball mill was not necessary because of poor aggregation of this sediment. Loess samples were crushed using a pestle and mortar and homogenized via shaking of ground samples in their flasks.

Bulk and lipid analyses

To measure $\mathrm{C}_{\text {org }}$ contents, aliquots $(0.5-2 \mathrm{~g})$ of all samples were combusted at $550^{\circ} \mathrm{C}$ using a furnace (Feststoffmodul 1300, AnalytikJena, Germany) connected to a N/C analyser (Multi 2100, AnalytikJena, Germany).
Another aliquot of each sample ( $\sim 30 \mathrm{~g}$ of soil or loess, $\sim 2-25 \mathrm{~g}$ of rhizoliths, 1-5 g of plant biomass) was extracted for free extractable lipids by Soxhlet extraction for at least $40 \mathrm{~h}$ using a solvent mixture of dichloromethane (DCM)/methanol (93:7; v:v; Wiesenberg et al. 2010). The neutral fractions were obtained from the total lipid extracts (TLEs) by chromatographic separation using solid phase extraction (SPE) with $\mathrm{KOH}$-coated silica gel $(5 \% \mathrm{KOH}$, Margot Köhnen-Willsch) with DCM as solvent (Wiesenberg et al. 2010). After reducing the solvent volume to dryness, the neutral fraction was dissolved in hexane and separated with respect to aliphatic and aromatic hydrocarbons, as well as low polarity hetero compounds, on columns filled with activated silica gel (100 Aं; Supelco), using solvent mixtures of hexane, hexane/DCM (1:1, v:v) and DCM/methanol (93:7, v:v), respectively (Gocke et al. 2010a). After addition of deuteriated standard for quantification $\left(\mathrm{D}_{50} \mathrm{C}_{24}\right.$ $n$-alkane), aliphatic hydrocarbons were measured by gas chromatography equipped with a flame ionisation detector (GC-FID, Agilent 7890) on a J\&W DB5 
column $(30 \mathrm{~m}$, inner diameter $0.32 \mathrm{~mm}$, film thickness $0.25 \mu \mathrm{m}) .1 \mu \mathrm{l}$ of alkanes were injected via splitless injection at $70^{\circ} \mathrm{C}$. After $3 \mathrm{~min}$ of isothermal conditions, temperature was raised to $140^{\circ} \mathrm{C}$ at a rate of $10^{\circ} \mathrm{C}$, followed by $5^{\circ} \mathrm{C} \mathrm{min}^{-1}$ until $310^{\circ} \mathrm{C}$. The final temperature was held for $16 \mathrm{~min}$.

\section{Lipid molecular proxies}

\section{Average chain length}

The ACL of alkanes is used to differentiate between predominantly higher plant derived OM (values $\geq 25$; Eglinton et al. 1962; Kolattukudy et al. 1976) and degraded OM or microorganism derived OM (values $<25$; Bray and Evans 1961). While odd long chain alkanes $\left(\geq \mathrm{C}_{25}\right)$ occur mainly in epicuticular waxes of higher plants, short chain alkanes mainly originate from microbial biomass and various degradation processes. In this study, ACL values for long chain alkanes $\left(\mathrm{ACL}_{\mathrm{lc}} ; \mathrm{C}_{25-33}\right)$ are shown to compare the different plant sources for loess, soil, rhizoliths and roots of recent vegetation.

$\mathrm{ACL}_{\mathrm{lc}}$ is calculated as follows:

$\mathrm{ACL}_{\mathrm{lc}}=\Sigma\left(z_{n} * n\right) / \Sigma\left(z_{n}\right)$

where $n$ is the number of carbons and $z_{n}$ the amount of alkanes with $n$ carbons, with $n$ in the range 25-33. ACL values representing the ACL ( $\left.\mathrm{ACL}_{\text {total }}, \mathrm{C}_{15-37}\right)$ of all identified and quantified alkanes are presented in Tables 1 and 2.

\section{Carbon preference index}

Long chain alkanes in fresh biomass from higher plants typically show a strong predominance of odd homologues (Eglinton et al. 1962; Kolattukudy et al. 1976), whereas even homologues derive mainly from degradation of OM (like e.g. primary wax remains of plants, alcohols, carboxylic acids and wax esters), leading to a decrease of the odd predominance (Zhou et al. 2005). High CPI values $(>10)$ are therefore typical for fresh plant biomass, while values $<10$ indicate degradation of OM (Cranwell 1981) or can be related to root biomass (Wiesenberg et al. unpublished data) due to the absence of epicuticular leaf waxes. Further, CPI values around 1 are characteristic for highly degraded OM and/or presence of large amounts of microorganism derived OM, because the latter comprises mainly short chain alkanes without even or odd predominance (Cranwell 1981; Zhou et al. 2005). $\mathrm{CPI}$ is calculated as follows:

$$
\begin{aligned}
\mathrm{CPI}= & {\left[\left(\sum n-\mathrm{C}_{25-33 \text { odd }} / \sum n-\mathrm{C}_{24-32 \text { even }}\right)\right.} \\
& \left.+\left(\sum n-\mathrm{C}_{25-33 \text { odd }} / \sum n-\mathrm{C}_{26-34 \text { even }}\right)\right] / 2
\end{aligned}
$$

Statistical analyses

Data sets $\left(\mathrm{C}_{\text {org }}\right.$ and lipid contents, alkane contents, CPI, $A C L_{1 c}, C_{27} / C_{31}$ ) were tested for significance of differences between sample types using one-way ANOVA with a significance level of 0.05 , followed by post hoc Scheffé test. These statistical evaluations were performed using STATISTICA 7.0 software (Statsoft).

\section{Results}

$\mathrm{C}_{\text {org }}$ contents

$\mathrm{C}_{\text {org }}$ contents of the sample set varied between less than $1 \mathrm{mg} \mathrm{g}^{-1}$ for some loess samples and up to $570 \mathrm{mg} \mathrm{g}^{-1}$ for plant parts, with a clear separation of values $<100 \mathrm{mg} \mathrm{g}^{-1}$ for loess, soil and rhizoliths (predominantly $<25 \mathrm{mg} \mathrm{g}^{-1}$; Fig. 1b), and significantly higher values $\left(\geq 270 \mathrm{mg} \mathrm{g}^{-1}\right)$ for recent plant biomass (Fig. 1b; Tables 1,2). Throughout the former part of the sample set, $\mathrm{C}_{\text {org }}$ contents were in general lowest for loess, highest for rhizoliths and intermediate for soil horizons. In grass (L. multiflorum), $\mathrm{C}_{\text {org }}$ content was higher in aboveground biomass compared to roots, while it was vice versa in the herb $T$. maritimum indorum. For the herb $S$. canadensis, $\mathrm{C}_{\text {org }}$ content of roots was higher than that of the stem, but lower than that of leaves. For one $R$. pseudoacacia plant, $\mathrm{C}_{\mathrm{org}}$ contents were similar in aboveground and root biomass, while for the other plant $\mathrm{C}_{\text {org }}$ content increased from roots via stem towards leaves (Fig. 1b).

For loess as well as rhizolith samples, $\mathrm{C}_{\text {org }}$ contents did not vary considerably with depth except for two rhizolith samples from a depth of 2.2-2.6 m. These exceeded $\mathrm{C}_{\text {org }}$ contents of $25 \mathrm{mg} \mathrm{g}^{-1}$, whereas all other soil, loess and rhizolith samples were characterized by lower $\mathrm{C}_{\text {org }}$ contents. LOM was always significantly lower than corresponding rhizolith samples of the same depth interval. Rhizoliths did not reach $\mathrm{C}_{\text {org }}$ contents of recent root biomass. 
Lipid extract yields

Similar to $\mathrm{C}_{\text {org }}$ contents, lipid extract yields (normalized to sample weight) were lowest in loess and rhizoloess $\left(56 \pm 8\right.$ and $81 \pm 12 \mu \mathrm{g} \mathrm{g}^{-1}$, respectively), soil $\left(188 \pm 29 \mu \mathrm{g} \mathrm{g}^{-1}\right)$ and rhizoliths $(191 \pm$ $40 \mu \mathrm{g} \mathrm{g}^{-1}$; Fig. 2b). In contrast, lipid contents (TLE) were considerably higher in fresh plant biomass, with values around $16 \mathrm{mg} \mathrm{g}^{-1}$ in recent root biomass and up to $67 \mathrm{mg} \mathrm{g}^{-1}$ in robinia leaves (Fig. 2a; Table 2).

Rhizoliths with identical TLE values like recent soil were characterized by higher $\mathrm{C}_{\text {org }}$ contents. Rhizoloess samples had intermediate $\mathrm{C}_{\text {org }}$ contents and TLE values between loess and rhizoliths.

When lipid contents are normalized to $\mathrm{C}_{\text {org }}$ contents, aboveground biomass had the highest lipid contents (79 $\pm 17 \mathrm{mg} \mathrm{g}^{-1} \mathrm{C}_{\mathrm{org}}$ ), followed by loess (43 \pm $13 \mathrm{mg} \mathrm{g}^{-1} \mathrm{C}_{\text {org }}$ ). The values were lower for roots $\left(38 \pm 10 \mathrm{mg} \mathrm{g}^{-1} \mathrm{C}_{\text {org }}\right.$ ). The lipid contents strongly decreased towards soil $\left(28 \pm 4 \mathrm{mg} \mathrm{g}^{-1} \mathrm{C}_{\text {org }}\right)$ and rhizoloess $\left(28 \pm 15 \mathrm{mg} \mathrm{g}^{-1} \mathrm{C}_{\text {org }}\right)$, with lowest contents for rhizoliths (14 $\pm 4 \mathrm{mg} \mathrm{g}^{-1} \mathrm{C}_{\text {org }}$; Tables 1,2$)$.

\section{n-Alkane contents and composition}

$\mathrm{C}_{\text {org }}$ normalized amounts of alkanes showed high variation throughout the sample set, usually with highest values for rhizoloess and loess samples $\left(2364 \pm 486 \mu \mathrm{g} \mathrm{g}^{-1} \quad \mathrm{C}_{\text {org }}\right.$ and $1095 \pm 369 \mu \mathrm{g} \mathrm{g}^{-1}$ $\mathrm{C}_{\text {org }}$, respectively), high values for aboveground plant biomass $\left(336 \pm 138 \mu \mathrm{g} \mathrm{g}^{-1} \quad \mathrm{C}_{\text {org }}\right.$ ) and rhizoliths $\left(261 \pm 100 \mu \mathrm{g} \mathrm{g}^{-1} \quad \mathrm{C}_{\text {org }}\right)$, and significantly $(p<$ 0.05 ) lower values for root biomass (especially for robinia; $59 \pm 22 \mu \mathrm{g} \mathrm{g}^{-1} \mathrm{C}_{\text {org }}$ ). The average $\mathrm{C}_{\text {org }}$ normalized amounts of alkanes in soil $(257 \pm$
$18 \mu \mathrm{g} \mathrm{g}^{-1} \mathrm{C}_{\text {org }}$ ) resembled the average rhizolith value (Tables 1,2).

The $n$-alkane distribution patterns with dominance of long chain odd homologues $\left(\mathrm{C}_{25+}\right)$ showed higher plant biomass as main source of OM in the whole sample set (Eglinton et al. 1962; Kolattukudy et al. 1976; Figs. 3, 4). The most abundant $n$-alkane in soil and loess samples was either $\mathrm{C}_{29}$ or $\mathrm{C}_{31}$. Loess $n$ alkane distribution patterns always maximized at $\mathrm{C}_{31}$ between 0.8 and $3.4 \mathrm{~m}$. Below, most abundant $n$ alkane was either $\mathrm{C}_{29}$ or $\mathrm{C}_{31}$ and did not correlate with distribution of paleosols and sediments, i.e. incipient and main tundra gleys (units 26, 28, 30a, 30b, 33) and typical loess. For most of the rhizoliths $n$-alkanes maximized at $\mathrm{C}_{29}$, while $\mathrm{C}_{31}$ was also rather abundant. In aboveground plant biomass, the most abundant $n$ alkane was $\mathrm{C}_{31}$ in L. multiflorum, $\mathrm{C}_{29}$ in T. maritimum indorum, $\mathrm{C}_{31}$ in $S$. canadensis leaves, and $\mathrm{C}_{27}$ in $R$. pseudoacacia leaves (Fig. 3).

Short chain $n$-alkanes $\left(\mathrm{C}_{15-24}\right)$ were absent in fresh plant aboveground biomass and occurred in traces in root biomass. However, even numbered $n$-alkanes $\left(\mathrm{C}_{16,18,20}\right)$, deriving mainly from degradation and microbial OM, were slightly enriched in soil, rhizoliths and sediments, and especially in rhizosphere loess (not shown here).

\section{Ratio of $C_{27} / C_{31}$ alkanes}

The $\mathrm{C}_{27} / \mathrm{C}_{31}$ ratio varied for fresh plant biomass between 0.07 for grass aboveground biomass and 40 for robinia aboveground biomass (Fig. 5). SOM and most of the loess and rhizolith samples were characterized by $\mathrm{C}_{27} / \mathrm{C}_{31}<1$, i.e. most rhizolith and loess samples contained higher amounts of $\mathrm{C}_{31}$ compared to
Fig. $2 \mathrm{C}_{\text {org }}$ and lipid contents of recent plant biomass, rhizoliths, loess and soil $\mathbf{a}$ for the whole sample set and $\mathbf{b}$ for rhizoliths, rhizoloess, loess and soil as a detail from diagram (a)
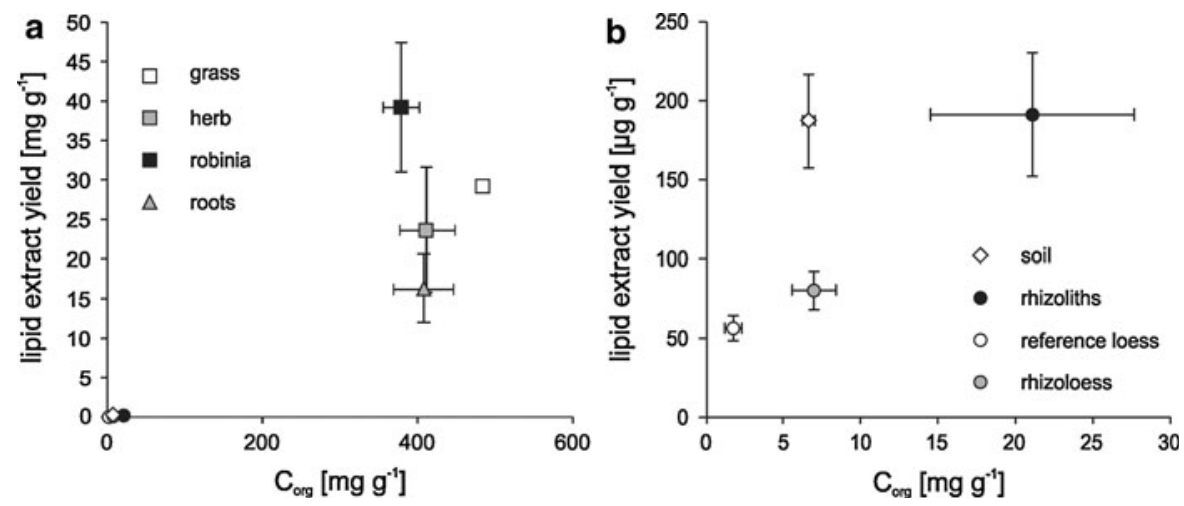
Fig. 3 Relative abundances of long chain $\left(\mathrm{C}_{27-33}\right)$ alkanes, normalized to the most abundant long chain alkane within each sample, of a aboveground biomass and roots of grass

(L. multiflorum), herbs

(T. maritimum indorum,

S. canadensis), and shrub (R. pseudoacacia) as well as of $\mathbf{b}$ roots deriving from individual soil horizons $\left(\mathrm{A}_{\mathrm{p}}\right.$ and $\mathrm{B}_{\mathrm{w} 2}$ )
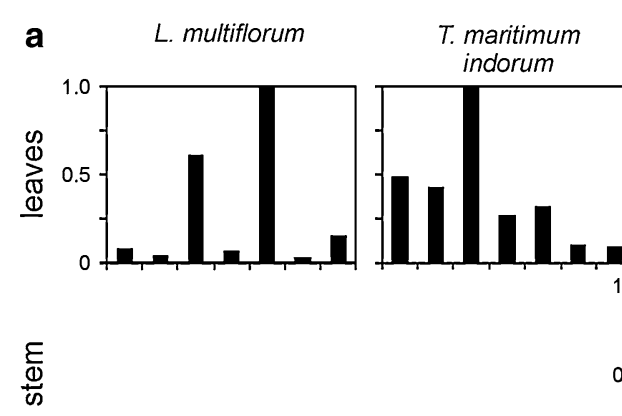

S. canadensis

R. pseudoarcacia
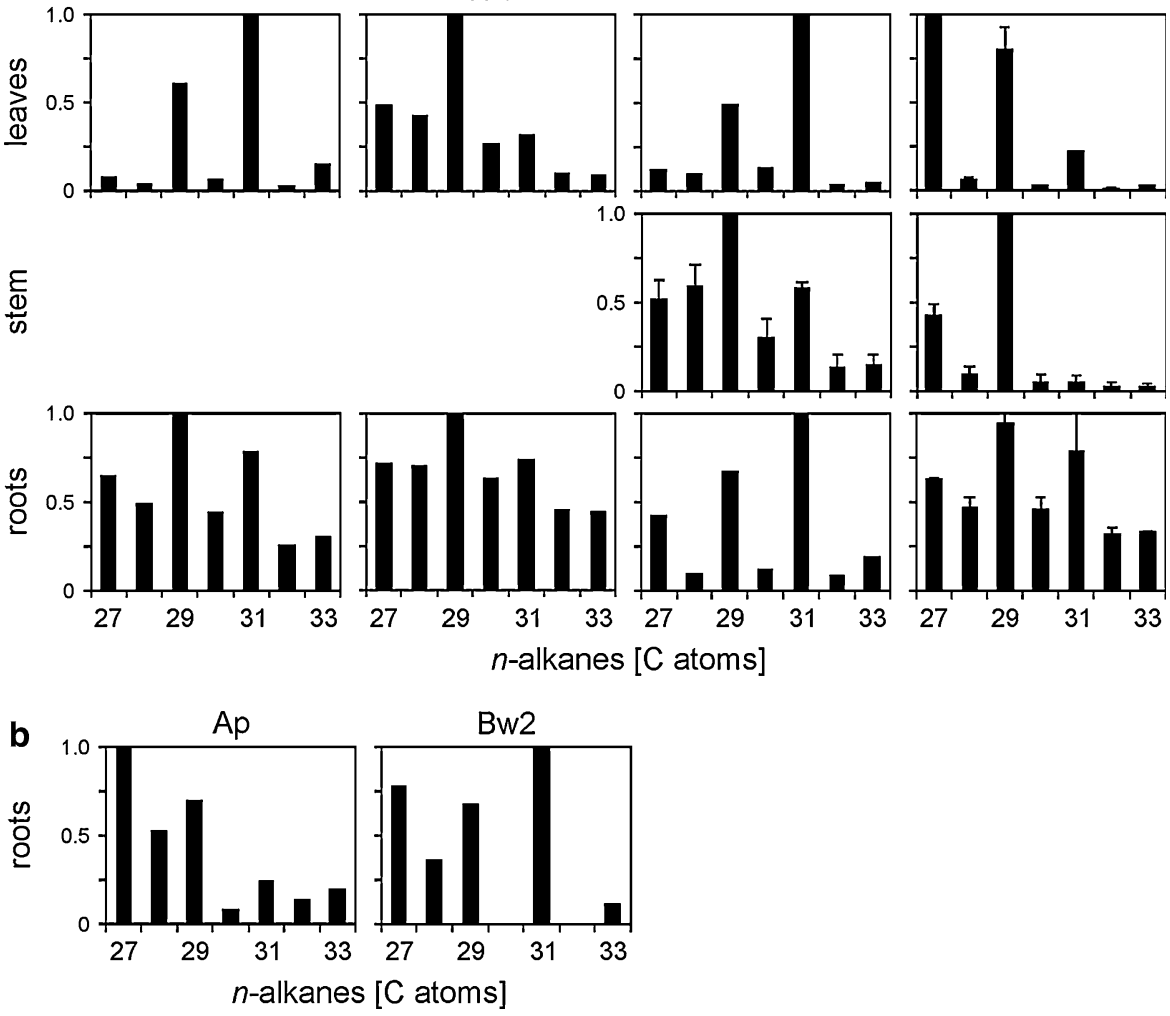

$\mathrm{C}_{27}$. Further, values of the ratios were generally higher in rhizoliths and corresponding rhizosphere loess compared to reference loess in the same depth interval. $\mathrm{C}_{27} / \mathrm{C}_{31}$ ratios in reference loess were only slightly higher than that of fresh grass aboveground biomass (Fig. 5).

\section{$A C L$ and CPI proxies}

$\mathrm{ACL}_{\mathrm{lc}}$ values in loess $(29.5 \pm 0.2)$ were lower than those of grass (30.2), but slightly higher than those of herb aboveground biomass $(29.1 \pm 0.2)$ as well as recent roots $(28.9 \pm 0.1)$, and substantially higher than those of robinia aboveground biomass (27.9 \pm 0.2 ; Fig. 6). $\mathrm{ACL}_{\mathrm{lc}}$ values of rhizosphere loess $(29.4 \pm 0.2)$ and soil $(29.5 \pm 0.1)$ were almost identical to those of loess, whereas rhizoliths $(29.0 \pm 0.3$; Fig. 6) had same values like roots.

$\mathrm{ACL}_{\text {total }}$ was similar or identical to $\mathrm{ACL}_{\mathrm{cc}}$ in grass (30.2), herb (28.7 \pm 0.2$)$ and robinia aboveground biomass $(27.7 \pm 0.2)$. However, $\mathrm{ACL}_{\text {total }}$ values were significantly $(p<0.01)$ lower than $\mathrm{ACL}_{\mathrm{lc}}$ in roots $(27.2 \pm 0.6), \quad$ rhizoliths $(23.7 \pm 1.3), \quad$ rhizoloess
$(25.8 \pm 0.5)$, loess $(23.6 \pm 1.1)$ and soil $(25.1 \pm$ 0.4; Tables 1,2).

CPI values revealed a wide range between 0.6 and 18.8 (Tables 1, 2), with lowest values in rhizoliths $(2.6 \pm 1.1)$, roots $(2.9 \pm 0.9)$ and herb aboveground biomass $(2.8 \pm 0.6)$, intermediate values in rhizosphere loess $(6.2 \pm 0.8)$, soil $(8.2 \pm 0.9)$ and loess $(9.4 \pm 1.3)$, and highest values in aboveground biomass from robinia $(13.0 \pm 2.0)$ and grass (16.1; Fig. 6). CPI values differed between aboveground biomass and rhizoliths $(p<0.05)$, roots and loess $(p<0.05)$, as well as between rhizoliths and loess $(p<0.01)$.

\section{Discussion}

Overview of the sample set

In general, the predominantly higher plant origin of the whole sample set was confirmed by the dominance of odd long chain $n$-alkanes (Eglinton et al. 1962; Kolattukudy et al. 1976). However, sample types 
Fig. 4 Relative abundances of long chain $\left(\mathrm{C}_{27-33}\right)$ alkanes, normalized to the most abundant long chain alkane within each sample, of rhizoliths, loess and soil depending on depth in the profile. For caption of the profile see Fig. 1. Similar to Fig. 3, only long chain alkanes $\left(\mathrm{C}_{27-33}\right)$ deriving from higher plant biomass (Eglinton et al. 1962; Kolattukudy et al. 1976) are shown for comparison of potentially different source vegetation of $\mathrm{OM}$

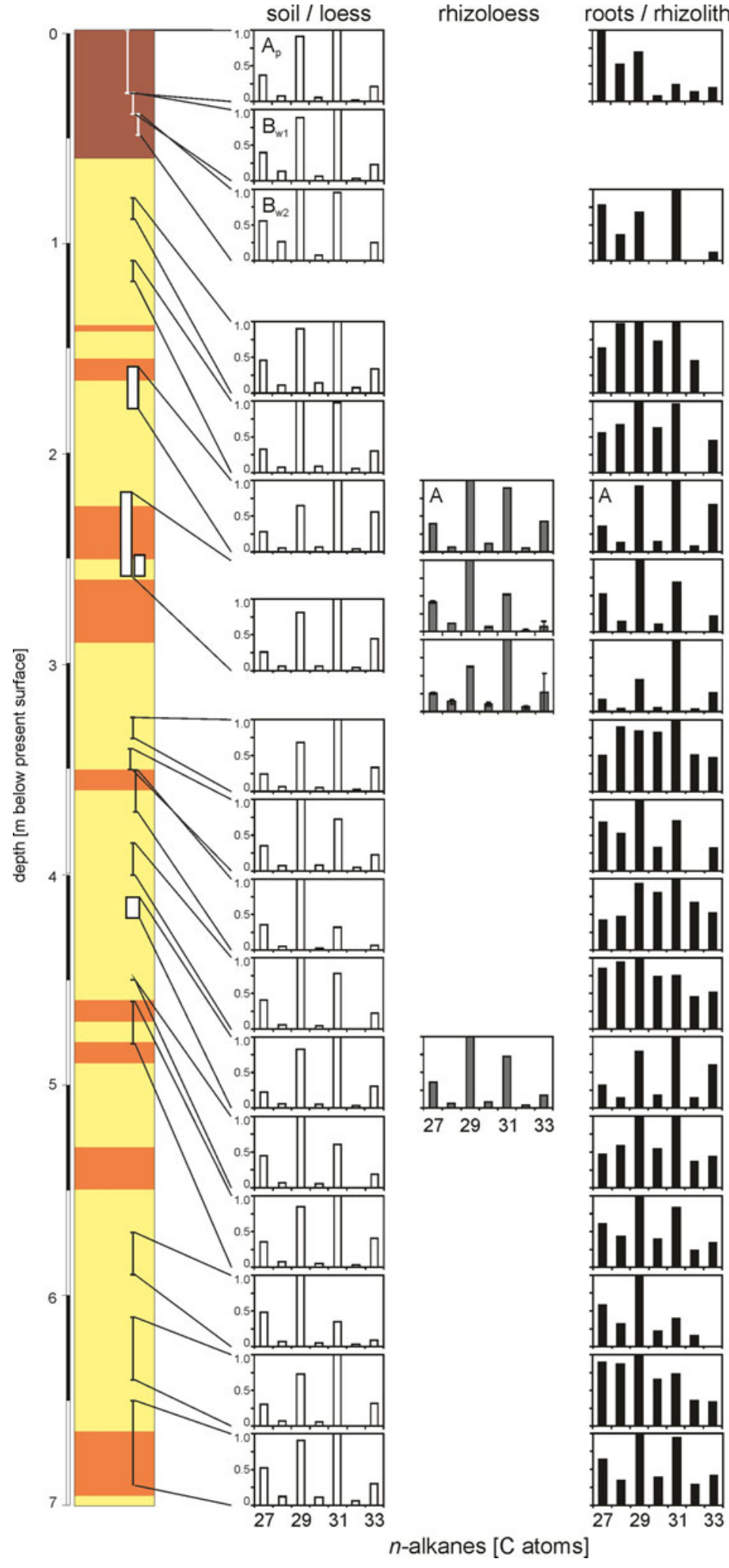




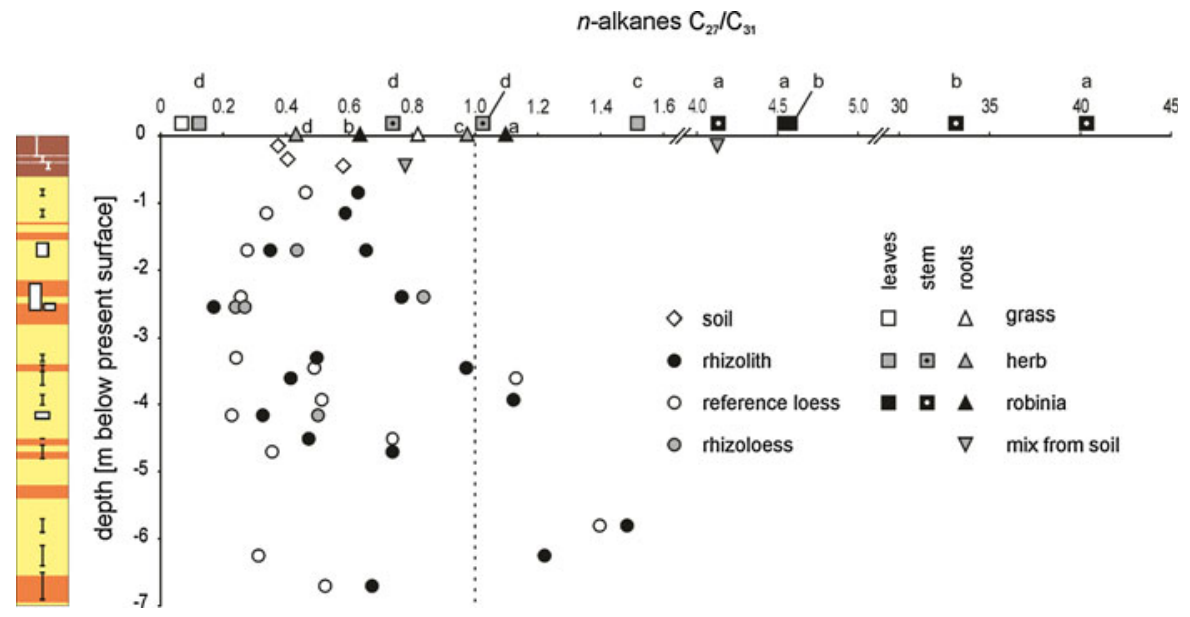

Fig. 5 Distribution of $\mathrm{C}_{27} / \mathrm{C}_{31}$ ratio in recent plant biomass ( $a$, $b=$ replicate plants of $R$. pseudoacacia, $c=T$. maritimum indorum, $d=S$. canadensis) and soil, rhizoliths and loess depending on depth in the profile. For caption of the profile see Fig. 1. As revealed by fresh plant biomass, tree aboveground biomass usually shows high ratios $>1$, while low values are

more typical for grass vegetation (Maffei 1996a; Schwark et al. 2002). This is also to some extent represented by loess and rhizoliths, with lower values of the former throughout major part of the profile, thereby indicating the grass origin of LOM. Note that $x$-axis was interrupted several times for improved illustration of data points
Fig. $6 \mathrm{ACL}_{\mathrm{lc}}$ and $\mathrm{CPI}$ values of plant biomass, rhizoliths, loess and soil. Both values indicate fresh biomass by high values, while degradation and incorporation of microbial remains lead to decreasing values (Kolattukudy et al. 1976)

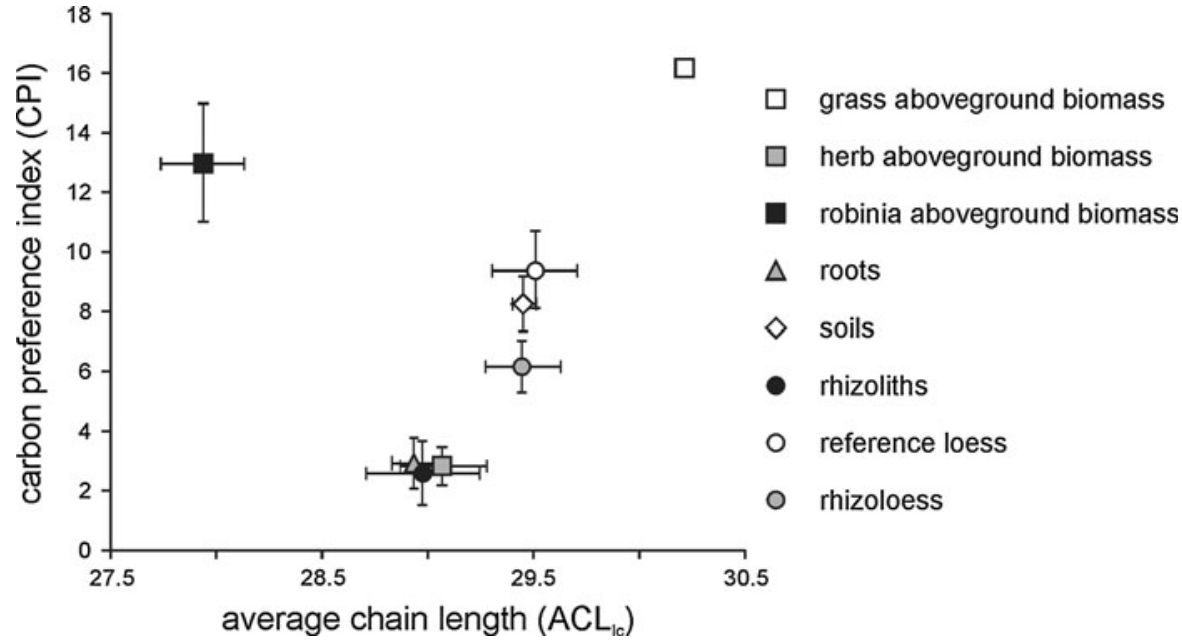

differed with respect to their degree of degradation, source vegetation and parts of source plants, as shown by several parameters.

Lower $\mathrm{C}_{\text {org }}$ contents were found in soil, rhizoliths and loess compared to fresh plant biomass (Fig. 1b) because of dilution of $\mathrm{OM}$ by high mineral content (especially in rhizoliths and loess) on one hand, and degradation of OM by biotic and abiotic processes since their formation/deposition on the other hand. Slightly higher $\mathrm{C}_{\text {org }}$ contents in rhizoliths compared to loess and soil samples (Fig. 1b) indicated the presence of former root tissues and its potentially improved preservation due to encrustation (Gocke et al. 2010a). Relatively high scatter between $\mathrm{C}_{\text {org }}$ contents of rhizoliths from different depth $\left(\sim 10-90 \mathrm{mg} \mathrm{g}^{-1}\right)$ was attributed to varying contents of primary minerals and secondary carbonate (Gocke et al. 2011). Alkane distribution patterns maximizing either at $\mathrm{C}_{29}$ or $\mathrm{C}_{31}$ as most abundant long chain $n$-alkane (Fig. 4) suggested various source plants for rhizoliths. 
Generally, samples with high $\mathrm{C}_{\text {org }}$ contents also contained large amounts of extractable lipids (Fig. 2), but this correlation was not identical in all sample types: loess was relatively enriched in lipids compared to $\mathrm{C}_{\text {org }}$ content, which could be attributed to the selective degradation and translocation of less stable organic compounds like e.g. water-soluble substances and sugars, whereas lipids were comparatively recalcitrant. This confirms investigations in recent soils (Marschner et al. 2008) and argues for the suitability of lipids for paleoenvironmental research in terrestrial sediments (e.g. Schwark et al. 2002; Xie et al. 2003, 2004; Zhou et al. 2005; Zech et al. 2009). The high lipid content in soil normalized to sample weight was caused mainly by incorporation of compounds that were derived from aboveground plant biomass, as also indicated by high $\mathrm{C}_{\text {org }}$ normalized alkane contents in soil (Table 1). Alkanes contribute substantially to epicuticular waxes (Kolattukudy et al. 1976) and have been incorporated in upper soil horizons via plant residues.

Lipid contents normalized to $\mathrm{C}_{\text {org }}$ revealed largest values for aboveground biomass $\left(79.3 \pm 16.5 \mathrm{mg} \mathrm{g}^{-1}\right)$, which were dissimilar from loess $\left(43.5 \pm 12.6 \mathrm{mg} \mathrm{g}^{-1}\right)$, roots $\left(38.5 \pm 10.1 \mathrm{mg} \mathrm{g}^{-1}\right)$, soil $\left(27.6 \pm 3.7 \mathrm{mg} \mathrm{g}^{-1}\right)$ and rhizoliths $\left(13.6 \pm 3.9 \mathrm{mg} \mathrm{g}^{-1}\right)$. In general, strong degradation of functionalized lipids including fatty acids (Kawamura et al. 1980), additional carbon sources like microorganisms, and components more recalcitrant than lipids (e.g. lignin) led to low lipid contents in loess and soil (Harwood and Russell 1984). However, strong degradation led to a decrease in the $\mathrm{TLE} / \mathrm{C}_{\text {org }}$ ratio via ongoing incorporation of fresh $\mathrm{OM}$ in soil while, in contrast, a higher $\mathrm{TLE} / \mathrm{C}_{\text {org }}$ ratio in loess resulted from preservation of recalcitrant lipids. Furthermore, lower $\mathrm{TLE} / \mathrm{C}_{\mathrm{org}}$ ratio of rhizoliths than for soil and recent roots revealed the degradation of the former root tissue, leading to a relative degradation of functionalized lipids. In contrast to $\mathrm{C}_{\text {org }}$ normalized lipid contents, $\mathrm{C}_{\text {org }}$ normalized alkane contents in rhizoliths $\left(261 \pm 100 \mu \mathrm{g} \mathrm{g}^{-1}\right)$ considerably exceeded those of recent root biomass $\left(60 \pm 22 \mu \mathrm{g} \mathrm{g}^{-1}\right)$, thus arguing for a relative enrichment of more recalcitrant alkanes compared to less stable compounds. Very low $\mathrm{C}_{\text {org }}$ normalized lipid contents of rhizoloess $\left(28.1 \pm 15.2 \mathrm{mg} \mathrm{g}^{-1}\right)$, with values similar to those of soil and between those of loess and rhizoliths, indicated that a part of OM in rhizoloess was incorporated from root derived $\mathrm{OM}$ in the former rhizosphere. This implies that degradation products of roots and fine root hairs, exudates and root-associated microbial remains led to incorporation of organic compounds other than lipids (e.g. lignin, sugars). Quantification of root derived compounds in rhizosphere loess was performed by Gocke et al. (2010a) using unsaturated fatty acids. Other root derived components that are potentially less prone to degradation compared to functionalized lipids like fatty acids, e.g. polymers like lignin or suberin (Mendez-Millan et al. 2010), can be assumed to result in the relative depletion of lipids in the former rhizosphere compared to loess distant from root remains.

Very high $\mathrm{C}_{\text {org }}$ normalized alkane contents in loess $\left(1,095 \pm 396 \mu \mathrm{g} \mathrm{g}^{-1}\right)$ and rhizoloess $(2,364 \pm 486$ $\left.\mu \mathrm{g} \mathrm{g}^{-1}\right)$ indicated the selective preservation of alkanes compared to other compounds of OM that are more easily degradable or more prone to translocation, like water-soluble compounds including carbohydrates (Marschner et al. 2008). In contrast, $\mathrm{C}_{\text {org }}$ normalized alkane contents for rhizoliths $\left(261 \pm 100 \mu \mathrm{g} \mathrm{g}^{-1}\right)$ were comparable to fresh aboveground plant biomass $\left(336 \pm 138 \mu \mathrm{g} \mathrm{g}^{-1}\right)$ and $\operatorname{SOM}\left(257 \pm 18 \mu \mathrm{g} \mathrm{g}^{-1}\right)$, indicating the relatively well preservation of former root tissue and root derived OM within the carbonatic crust. This agrees with previous studies based radiocarbon ages of rhizolith $\mathrm{OM}$ and carbonate (Gocke et al. 2011), demonstrating good preservation and Holocene age of former roots at Nussloch in contrast to late Pleistocene age of surrounding loess.

High amounts of short chain even homologues, leading to low $\mathrm{ACL}_{\text {total }}$ values especially in rhizoloess and in some of the rhizoliths, indicated the presence of high amounts of root and microorganism derived OM (Bray and Evans 1961; Eglinton et al. 1962; Kolattukudy et al. 1976) similar to the soil. This strongly suggests the presence of a former rhizosphere around the rhizoliths, which was a hot spot of microbial biomass feeding on root remains and exudates (Jones 1998), thus promoting biotic degradation of synsedimentary LOM as well as younger root derived OM.

In summary, $n$-alkane proxies, together with $\mathrm{C}_{\text {org }}$ contents and TLE, proved to be a valuable tool for source apportionment. For a more certain differentiation of vegetation sources further proxies deriving from free extractable fatty acids and $n$-alcohols, or potentially suberin and cutin molecular markers (Mendez-Millan et al. 2010), are necessary, which were not investigated in this study. 
Source apportionment of OM in loess, rhizoliths and soil

\section{Loess organic matter (LOM)}

Loess was characterized by lowest $\mathrm{C}_{\text {org }}$ contents (Fig. 1b) which suggests strongest degradation of LOM compared to other materials. Further, different source of OM input is likely, i.e. mainly by grass aboveground biomass and associated epicuticular waxes, leading to more homogeneous OM distribution in loess compared to local input of OM by former roots, which can also be related to various turbations (cryoturbation and bioturbation) as frequently abundant in loess sediments (Pye 1995). Loess samples were mostly dominated by $\mathrm{C}_{31}$ and sometimes by $\mathrm{C}_{29}$ as most abundant long chain $n$-alkane (Fig. 4). The generally very low values of the $\mathrm{C}_{27} / \mathrm{C}_{31}$ ratio are typically related to grass vegetation (Maffei 1996a; Schwark et al. 2002). A part of the rhizoliths was also characterized by $n-\mathrm{C}_{31}$ as most abundant long chain alkane (Fig. 4). However, ratios of $\mathrm{C}_{27} / \mathrm{C}_{31} n$-alkanes were always higher in rhizolith than in the corresponding loess from the same depth (Fig. 5), indicating that rhizolith $\mathrm{OM}$ is less related to grass vegetation than LOM.

Additionally, CPI and $\mathrm{ACL}_{\mathrm{lc}}$ values of loess were rather high compared to root biomass and rhizoliths, similarly to recent grass aboveground biomass (Fig. 6), thereby arguing that LOM can be attributed mainly to aboveground biomass of grass vegetation. This agrees with the general assumption of loess deposition taking place during glacial periods with scarce vegetation cover, consisting mainly of grass plants with low incorporation of tree derived OM (Bai et al. 2009). In contrast to tree and shrub roots, grass roots commonly do not penetrate soil and underlying sediments down to large depths of several meters (Canadell et al. 1996). This means that the ratio of shoot versus root derived $\mathrm{OM}$ in soils under grass vegetation and loess must be higher compared to soil under forest and shrub vegetation. Thus, LOM is commonly characterized by alkane composition which resembles grass aboveground biomass and is not related to root biomass.

Although LOM and SOM showed similar relative n-alkane distribution, with $\mathrm{C}_{31}$ as most abundant long chain homologue (Fig. 4) and similar CPI and $\mathrm{ACL}_{\mathrm{lc}}$ values (Fig. 6), they could be clearly differentiated due to lower values of the $\mathrm{TLE} / \mathrm{C}_{\text {org }}$ ratio (see "Overview of the sample set" section) and substantially higher total alkane contents in loess than in soil. The higher abundance of alkanes in loess was most likely caused by selective preservation especially of long chain alkanes in loess as previously described for soil (Lichtfouse et al. 1998).

Values of CPI (4.2 and 7.5), ACL (21.6 and 24.1) and $A C L_{\mathrm{lc}}$ (29.2 and 29.6) ratios were low in loess in a depth of $0.8-0.9$ and $1.1-1.2 \mathrm{~m}$, respectively (Table 1). In deeper parts of the profile higher values predominated. This indicates the modification of original sedimentary LOM in the uppermost part of the profile, where percolating soil solution together with microbial activity led to degradation of alkanes and hence modification of molecular proxies. With depth, no clear trends of increasing or decreasing $\mathrm{ACL}_{\mathrm{lc}}$ (28.8-30.2) and CPI (4.2-15.3) values were observable, which argues for different sources of $\mathrm{OM}$ in individual depths. Exceptionally high CPI values of loess $(>10)$ in a depth of $2.2-3.35$ and $3.5-4.2 \mathrm{~m}$ might be due to a low stage of degradation of the $\mathrm{OM}$ therein, which might be related to high sedimentation rates of the typical loess and low overprinting by soil forming processes in this part of the depth profile (Antoine et al. 2009).

\section{Rhizoliths and rhizoloess}

As already suggested by their size, shape and micromorphology (Klappa 1980; Becze-Deák et al. 1997; Gocke et al. 2011), rhizoliths represent calcified roots. This was confirmed by low $\mathrm{CPI}$ and $\mathrm{ACL}_{\mathrm{lc}}$ values of rhizoliths which were in the same range like roots of recent plants (Fig. 6). Except for robinia with exceptionally low $\mathrm{ACL}_{\mathrm{lc}}$ and herbs with surprising low CPI, rhizoliths together with recent roots revealed the lowest $A C L_{l c}$ and CPI values. This is because roots on one hand contain higher portions of even long chain alkanes than aboveground biomass (Wiesenberg et al. unpublished data), causing low CPI values, and on the other hand roots and rhizoliths cannot be completely separated from associated microorganisms which contribute $\mathrm{OM}$ with high abundance of short chain alkanes and without predominance of odd or even homologues, causing low ACL and CPI values (Cranwell 1981; Kolattukudy et al. 1976).

Although $\mathrm{ACL}_{\mathrm{lc}}$ and $\mathrm{CPI}$ values of rhizoliths were not uniform with depth, thereby showing their 
possibly diverse origin, values were always lower in rhizoliths and, where available, also lower in rhizoloess compared to reference loess. Hence, rhizoliths could be clearly differentiated from loess, whereas rhizoloess revealed commonly intermediate signals (in $\mathrm{C}_{\text {org }}$ contents, TLE and alkane composition) between LOM and rhizolith OM. This indicated the presence of both root and loess derived $\mathrm{OM}$ in rhizoloess (Gocke et al. 2010a, 2011). Depending on the amount of root-associated modification of sedimentary LOM, including root remains, root exudates and microbial remains and related degradation of LOM, the rhizosphere up to a distance of at least $5 \mathrm{~cm}$ from former roots showed either signals similar to rhizolith OM (partly most abundant long chain alkane, $\left.\mathrm{C}_{27} / \mathrm{C}_{31}\right)$ or LOM $\left(\mathrm{C}_{\text {org }}\right.$ contents, TLE).

The current data set does not allow for a specific source apportionment of rhizoliths. The most abundant alkanes (often $\mathrm{C}_{29}$ ), CPI and ACL values argue for a tree or shrub origin, which was different from robinia as their results were not identical: Except for the lowermost part $(4.5-6.9 \mathrm{~m})$, distribution patterns of rhizoliths did not resemble those of robinia roots (Figs. 3, 4). Average CPI values of rhizoliths $(2.6 \pm 1.1)$ were considerably higher compared to robinia roots (1.5 and 1.6, Table 1). Additionally, the $\mathrm{C}_{27} / \mathrm{C}_{31}$ ratio of rhizoliths $(0.7 \pm 0.1)$, although showing a high scatter, was mostly lower than that of robinia roots $(0.9 \pm 0.1$; Fig. 5$)$. As shown by several parameters including lipid contents and alkane distribution patterns, the present vegetation with robinia of sizes not larger than $3 \mathrm{~m}$ of height, some herbs and grasses cannot be potential source vegetation of rhizolith OM. As the site was managed as agricultural plot for at least several decades, implying annual ploughing and predominantly grass type crops, it is currently unknown which trees or shrubs led to the formation of the rhizoliths. The varying shape (diameter, length and structure) and molecular proxies of rhizoliths point out on mixed vegetation consisting of shrubs and trees, which had the ability to deeply root the sedimentary profile. As the ${ }^{14} \mathrm{C}$ age of a single rhizolith from the Nussloch profile from a depth of $1.3 \mathrm{~m}$ (3100 years BP) confirms the old age of the rhizoliths (Gocke et al. 2011), it can be assumed that the rhizoliths were formed by the rural vegetation without or with low anthropogenic influence. The type of vegetation in SW Germany at that time is assumed to be a mixed forest with trees including beech, oak and several shrubs. Therefore, it is most likely that these trees and shrubs, which partially have the ability to deeply root the underlying soil, sediment and rock, were the source plants of the rhizoliths. When comparing alkane composition from beech (including Fagus sylcatica), alder (Alnus sp.), oak (Quercus robur) and hazelnut (Corylus avellana) (Gülz et al. 1989; Prasad and Gülz 1990; Prasad et al. 1990; Sachse et al. 2006) as some of the predominant plant species in SW Germany 3000 years BP (Clark et al. 1989) with rhizoliths, it can be assumed that roots of such native tree and shrub species formed rhizoliths. However, commonly root lipid composition differs from that of aboveground biomass. Lacking knowledge of the lipid composition of a wide range of tree and shrub roots impedes correlation of these to rhizolith OM.

\section{Soil organic matter (SOM)}

Lipid contents in soil corresponded well to literature data from temperate agricultural soils $\left(227 \pm 80 \mu \mathrm{g} \mathrm{g}^{-1}\right.$; Wiesenberg et al. 2006). The alkane composition of the recent soil, including most abundant compounds and $\mathrm{C}_{27} / \mathrm{C}_{31}$ ratio, differed from roots obtained from $\mathrm{A}_{\mathrm{p}}$ and $\mathrm{B}_{\mathrm{w} 2}$ horizons. Additionally, roots of the recent vegetation and aboveground biomass did not show the same molecular distribution patterns like the soil (Figs. 3, 4). Grass biomass with high $n$ - $\mathrm{C}_{31}$ alkane content was one possible main contributor to SOM. Taking into account the former agricultural use of this site and comparing the alkane patterns of soil with those of other crop plants (Cayet and Lichtfouse 2001; Wiesenberg et al. 2004), crops like wheat, rye, maize and others were most likely predominant sources of SOM at Nussloch. Hence, the grass origin of both, SOM and LOM, resulted in a similar alkane composition of loess and soil. The major difference between these samples was observed for $\mathrm{C}_{\text {org }}$ normalized TLE and alkane contents (see "Overview of the sample set" and "Source apportionment of OM in loess, rhizoliths and soil" sections). The former tree vegetation as reflected in rhizoliths was neither observed in loess nor in soil, where the continuous incorporation of plant derived components since forest clearing and erosion of the rural soil led to an overprinting of the natural SOM origin. This is accompanied by the turnover of alkanes in soil ranging from decades (Wiesenberg et al. 2004; Marschner et al. 2008) to millennia (Bol et al. 1996; 
Rethemeyer et al. 2004), which is strongly influenced by soil management and plant biomass input.

A slight decrease of $\mathrm{ACL}_{\mathrm{lc}}$ and a strong decrease of CPI with depth (Table 1) indicated limited incorporation of aboveground biomass and predominantly root origin of lipids in deeper soil horizons. Additionally, stronger degradation of plant biomass can be assumed in greater soil depth (Buggle et al. 2010).

Implications for paleoenvironmental studies

Molecular proxies and lipid contents clearly argue for different source vegetation of rhizoliths from recent plant biomass, SOM and LOM. In some depth intervals, the values of the $\mathrm{C}_{27} / \mathrm{C}_{31}$ ratio of rhizoliths showed a similar tendency like loess: Where the value increased in rhizoliths it was observed similarly for loess of the same depth (e.g. depth 4.1-4.8 m) and vice versa (e.g. depth $0.8-1.8 \mathrm{~m}$ ), but commonly to a lesser degree. This might entail that even reference loess samples, which were carefully sampled from areas free of visible root remains, were nevertheless influenced by former soil forming processes, e.g. by percolating soil solutions.

At the Nussloch site, the $\mathrm{CPI}$ and $\mathrm{C}_{27} / \mathrm{C}_{31}$ ratio revealed contamination of original LOM by OM input from recent soil e.g. via percolating soil solution exclusively for the uppermost $\sim 60 \mathrm{~cm}$ below the recent $B_{w 2}$ horizon (Fig. 5; Table 1). Therefore 'new' $\mathrm{OM}$ in rhizoloess below depth of $1.6 \mathrm{~m}$ could be clearly attributed to former roots based on $\mathrm{C}_{\text {org }}$ and lipid contents (Fig. 2) and CPI values (Fig. 6). This confirmed a previous study (Gocke et al. 2010a), where root and microbial derived OM was quantified in rhizosphere loess based on fatty acids. In general, paleoenvironmental studies based on bulk carbon analyses including $\delta^{13} \mathrm{C}_{\mathrm{org}}$ or ${ }^{14} \mathrm{C}$ dating of LOM (e.g. Hatté et al. 1999) should be regarded with caution (Head et al. 1989). Some $\delta^{13} \mathrm{C}_{\text {org }}$ values out of typical range (e.g. Pustovoytov and Terhorst 2004) and often un-fitting ${ }^{14} \mathrm{C}$ ages (e.g. Hatté et al. 1999; Rousseau et al. 2007; Fuchs and Wagner 2005) might be caused by postsedimentary incorporation of root derived OM from deep-rooting plants (trees or shrubs). This is clearly of special importance for sediments with a high frequency of postsedimentary roots (in Nussloch up to $\sim 190$ rhizoliths $\mathrm{m}^{-2}$ ). However, it cannot be excluded that such effects can also be relevant in sediments with visible root remains without obvious stratigraphic layers or with incipient soils. Here, the missing layers are frequently attributed to turbation of various origin including cryoturbation and plant root activity (e.g. Pye 1995; Antoine et al. 2001; Mason et al. 2007). If such stratigraphic layers are present in a range of $\mathrm{mm}$ to $\mathrm{cm}$ and initial soil forming processes can be excluded, postsedimentary impregnation by roots is unlikely and associated processes might be neglected.

\section{Conclusions}

Alkane molecular proxies enabled differentiation of biogenic sources in the Nussloch soil and loess profile. OM from loess and soil were both derived from grass vegetation. Translocation of alkanes from soil towards underlying sediment via bioturbation or leaching is not likely. The uppermost part $(\sim 60 \mathrm{~cm})$ of the loess profile was influenced by pedogenic processes that led to changes in composition and abundances of $n$ alkanes. The recent vegetation did not contribute significantly to soil alkane composition, because due to the slow turnover of alkanes in soil the overprinting of the former agricultural derived OM during a few years was low.

The recent vegetation did not contribute to $\mathrm{OM}$ within and loess adjacent to rhizoliths. These calcified roots were formed under native tree and/or shrub vegetation, which likely was dominated by beech, oak, alder and hazelnut. The diversity of rhizolith alkane distribution patterns and morphology of rhizoliths argues for their formation under various plant species, and possibly during different time intervals throughout the Holocene. The overprinting of LOM even in areas distant to former roots could not be excluded as revealed by molecular proxies like ACL or CPI. Therefore, paleoenvironmental investigations of terrestrial sediments based only on bulk carbon analyses should be regarded with caution. Molecular proxies provide information on potential postsedimentary processes, which also influence bulk carbon composition and can lead to modifications in $\delta^{13} \mathrm{C}$ values and ${ }^{14} \mathrm{C}$ contents.

Further investigations on recent root biomass and multiple rhizoliths from the same depth and additional profiles are required to assess the source vegetation of 
these rhizoliths more reliably. Additionally, rhizoloess must be investigated in more detail and based on further compounds (e.g. fatty acids, $n$-alcohols or suberin and cutin derived monomers) to assess the postsedimentary modification of LOM beside the former roots and to determine the extension of the former rhizosphere, i.e. if effects of rhizosphere processes were restricted to few $\mathrm{cm}$ near roots or could extend to several $\mathrm{dm}$ into the surrounding sediment.

Acknowledgments This study was financially supported by German Research Foundation (DFG) under contract WI 2810/10. The authors thank the HeidelbergCement AG for giving the permission to sample in their quarries, R. Stahlmann for identification of plants sampled at Nussloch, and M. Löscher for help in the field. L. Zöller is gratefully acknowledged for improvements of the stratigraphic profile of the loess-paleosol sequence at Nussloch. The comments of two anonymous reviewers are also acknowledged.

\section{References}

Antoine P, Rousseau DD, Zöller L, Lang A, Munaut AV, Hatté C, Fontugne M (2001) High-resolution record of the last interglacial-glacial cycle in the Nussloch loess-palaeosol sequences, Upper Rhine Area, Germany. Quat Int 76(77): 211-229

Antoine P, Rousseau DD, Moine O, Kunesch S, Hatté C, Lang A, Tissoux H, Zöller L (2009) Rapid and cyclic aeolian deposition during the Last Glacial in European loess: a high-resolution record from Nussloch, Germany. Quat Sci Rev 28:2955-2973

Bai Y, Fang XM, Nie JS, Wang XL, Wu FL (2009) A preliminary reconstruction of the paleoecological and paleoclimatic history oft the Chinese Loess Plateau from the application of biomarkers. Palaeogeogr Palaeoclimatol Palaeoecol 271:161-169

Becze-Deák J, Langohr R, Verrecchia E (1997) Small scale secondary $\mathrm{CaCO}_{3}$ accumulations in selected sections of the European loess belt: morphological forms and potential for paleoenvironmental reconstruction. Geoderma 76: 221-252

Bol R, Huang Y, Meridith JA, Eglinton G, Harkness DD, Ineson $\mathrm{P}(1996)$ The ${ }^{14} \mathrm{C}$ age and residence time of organic matter and its lipid constituents in a stagnohumic gley soil. Eur J Soil Sci 47:215-222

Bray EE, Evans ED (1961) Distribution of $n$-paraffins as a clue to the recognition of source beds. Geochim Cosmochim Acta 22:2-15

Buggle B, Wiesenberg G, Glaser B (2010) Is there a possibility to correct fossil $n$-alkane data for postsedimentary alteration effects? Appl Geochem 25:947-957

Canadell J, Jackson RB, Ehleringer JR, Mooney HA, Sala OE, Schulze ED (1996) Maximum rooting depth of vegetation types at the global scale. Oecologia 108:583-595
Cayet C, Lichtfouse E (2001) $\delta^{13} \mathrm{C}$ of plant-derived $n$-alkanes in soil particle-size fractions. Org Geochem 32:253-258

Clark JS, Merkt J, Muller H (1989) Post-glacial fire, vegetation, and human history on the Northern Alpine Foreland, South-Western Germany. J Ecol 77:897-925

Cranwell PA (1981) Diagenesis of free and bound lipids in terrestrial detritus deposited in a lacustrine sediment. Org Geochem 3:79-89

Eglinton G, Gonzalez AG, Hamilton RJ, Raphael RA (1962) Hydrocarbon constituents of the wax coatings of plant leaves: a taxonomic survey. Phytochemistry 1:89-102

Food and Agriculture Organization of the United Nations/FAO (2006) World reference base for soil resources 2006. World Soil Resources Report No. 103. FAO, Rome

Fuchs M, Wagner GA (2005) The chronostratigraphy and geoarchaeological significance of an alluvial geoarchive: comparative OSL and AMS ${ }^{14} \mathrm{C}$ dating from Greece. Archaeometry 47:849-860

Galović L, Frechen M, Halamić J, Durn G, Romić M (2009) Loess chronostratigraphy in Eastern Croatia-a luminescence dating approach. Quat Int 198:85-97

Gocke M, Wiesenberg GLB, Pustovoytov K, Kuzyakov Y (2010a) Rhizoliths in loess-evidence for post-sedimentary incorporation of root-derived organic matter in terrestrial sediments as assessed from molecular proxies. Org Geochem 41:1198-1206

Gocke M, Pustovoytov K, Kuzyakov Y (2010b) Carbonate recrystallization in root-free soil and rhizosphere of Triticum aestivum and Lolium perenne estimated by ${ }^{14} \mathrm{C}$ labeling. Biogeochemistry 103:209-222

Gocke M, Pustovoytov K, Kühn P, Wiesenberg GLB, Löscher M, Kuzyakov Y (2011) Carbonate rhizoliths in loess and their implications for paleoenvironmental reconstructionrevealed by isotopic composition: $\delta 13 \mathrm{C}, 14 \mathrm{C}$. Chem Geol 283:251-260

Gülz PG, Müller E, Prasad RBN (1989) Organo-specific composition of epicuticular waxes of beech (Fagus sylvatica L.) leaves and seeds. Z Naturforsch C 44:731-734

Harwood JL, Russell NJ (1984) Lipids in plants and microbes. George Allen \& Unwin, London

Hatté C, Guiot J (2005) Palaeoprecipitation reconstruction by inverse modelling using the isotopic signal of loess organic matter: application to the Nußloch loess sequence (Rhine Valley, Germany). Clim Dyn 25:315-327

Hatté C, Fontugne M, Rousseau DD, Antoine P, Zöller L, Tisnerat-Laborde N, Bentaleb I (1998) $\delta^{13} \mathrm{C}$ variations of loess organic matter as a record of the vegetation response to climatic changes during the Weichselian. Geology 26: $583-586$

Hatté C, Antoine P, Fontugne M, Rousseau DD, Tisnerat-Laborde N, Zöller L (1999) New chronology and organic matter $\delta^{13} \mathrm{C}$ paleoclimatic significance of Nußloch loess sequence (Rhine Valley, Germany). Quat Int 62:85-91

Head MJ, Zhou WJ, Zhou MF (1989) Evaluation of ${ }^{14} \mathrm{C}$ ages of organic fractions of paleosols from loess-paleosol sequences near Xian, China. Radiocarbon 31:680-694

Jones DL (1998) Organic acids in the rhizosphere - a critical review. Plant Soil 205:25-44

Kawamura K, Ishiwatari R, Yamazaki M (1980) Identification of polyunsaturated fatty acids in surface lacustrine sediments. Chem Geol 28:31-39 
Klappa CF (1980) Rhizoliths in terrestrial carbonates: classification, recognition, genesis and significance. Sedimentology 27:613-629

Kolattukudy PE, Croteau R, Buckner JS (1976) Biochemistry of plant waxes. In: Kolattukudy PE (ed) Chemistry and Biochemistry of natural waxes. Elsevier, Amsterdam, pp 290-347

Kuhn TK, Krull ES, Bowater A, Grice K, Gleixner G (2010) The occurrence of short chain $n$-alkanes with an even over odd predominance in higher plants and soils. Org Geochem 41:88-95

Lang A, Hatté C, Rousseau DD, Antoine P, Fontugne M, Zöller L, Hambach U (2003) High-resolution chronologies for loess: comparing AMS ${ }^{14} \mathrm{C}$ and optical dating results. Quat Sci Rev 22:953-959

Lichtfouse E, Wehrung P, Albrecht P (1998) Plant wax $n$ alkanes trapped in soil humin by noncovalent bonds. Naturwissenschaften 85:449-452

Liu T, Guo Z, Wu N, Lu H (1996) Prehistoric vegetation on the Loess Plateau: steppe or forest? J Southeast Asian Earth Sci 13:341-346

Liu W, Yang H, Ning Y, An Z (2007) Contribution of inherent organic carbon to the bulk $\delta^{13} \mathrm{C}$ signal in loess deposits from the arid western Chinese Loess Plateau. Org Geochem 38:1571-1579

Machalett B, Oches EA, Frechen M, Zöller L, Hambach U, Mavlyanova NG, Marković SB, Endlicher W (2008) Aeolian dust dynamics in central Asia during the Pleistocene: driven by the long-term migration, seasonality, and permanency of the Asiatic polar front. Geochem Geophys Geosyst 9:Q08Q09

Maffei M (1996a) Chemotaxonomic significance of leaf wax alkanes in the Gramineae. Biochem Syst Ecol 24:53-64

Maffei M (1996b) Chemotaxonomic significance of leaf wax alkanes in the Umbelliferae, Cruciferae and Leguminosae (Subf. Papilionoideae). Biochem Syst Ecol 24:531-545

Marschner B, Brodowski S, Dreves A, Gleixner G, Gude A, Grootes PM, Hamer U, Heim A, Jandl G, Ji R, Kaiser K, Kalbitz K, Kramer C, Leinweber P, Rethemeyer J, Schäffer A, Schmidt MWI, Schwark L, Wiesenberg GLB (2008) How relevant is recalcitrance for the stabilization of organic matter in soils? J Plant Nutr Soil Sci 171:91-110

Mason JA, Joeckel RM, Bettis EA (2007) Middle to Late Pleistocene loess record in eastern Nebraska, USA, and implications for the unique nature of Oxygen Stage 2. Quat Sci Rev 26:773-792

Mendez-Millan M, Dignac MF, Rumpel C, Rasse DP, Derenne $S$ (2010) Molecular dynamics of shoot vs. root biomarkers in an agricultural soil estimated by natural abundance ${ }^{13} \mathrm{C}$ labelling. Soil Biol Biochem 42:169-177

Porter SC, An Z (1995) Correlation between climatic events in the North Atlantic and China during the last glaciation. Nature 375:305-308

Prasad RBN, Gülz PG (1990) Development and seasonal variations in the epicuticular waxes of beech leaves (Fagus sylvatica $\mathrm{L}$.). Z Naturforsch 45:805-812

Prasad RBN, Müller E, Gülz PG (1990) Epicuticular waxes from leaves of Quercus robur. Phytochemistry 29:2101-2103

Pustovoytov K, Terhorst B (2004) An isotopic study of a late Quaternary loess-paleosol sequence in SW Germany. Revista Mex Ciencias Geol 21:88-93
Pye K (1995) The nature, origin and accumulation of loess. Quat Sci Rev 14:653-667

Pye K, Sherwin D (1999) Loess. Ch. 10. In: Goudie AS, Livingstone I, Stokes S (eds) Aeolian environments, sediments and landforms. Wiley, Chichester, pp 213-238

Rethemeyer J, Kramer C, Gleixner G, Wiesenberg GLB, Schwark L, Andersen N, Nadeau MJ, Grootes PM (2004) Complexity of soil organic matter: AMS ${ }^{14} \mathrm{C}$ analysis of soil lipid fractions and individual compounds. Radiocarbon 46:465-473

Rousseau DD, Sima A, Antoine P, Hatté C, Lang A, Zöller L (2007) Link between European and North Atlantic abrupt climate changes over the last glaciation. Geophys Res Lett 34:L22713

Sachse D, Radke J, Gleixner G (2006) $\delta$ D values of individual $n$ alkanes from terrestrial plants along a climatic gradientimplications for the sedimentary biomarker record. Org Geochem 37:469-483

Schwark L, Zink K, Lechterbeck J (2002) Reconstruction of postglacial to early Holocene vegetation history in terrestrial Central Europe via cuticular lipid biomarkers and pollen records from lake sediments. Geology 30:463-466

Stahr K, Herrmann L (1996) Origin, deposition, and composition of dust, and consequences for soil and site properties with special reference to the semi-arid regions of West Africa. In: Buerker B, Allison BE, Oppen M (eds) Wind erosion in Niger. Developments in plant and soil sciences, vol 67. Kluwer, Amsterdam, pp 45-65

Wang H, Ambrose SH, Liu CLJ, Follmer LR (1997) Paleosol stable isotope evidence for early hominid occupation of East Asian temperate environments. Quat Res 48:228-238

Wiesenberg GLB, Schwarzbauer J, Schmidt MWI, Schwark L (2004) Sources and turnover of organic matter in agricultural soils derived from $n$-alkane $/ n$-carboxylic acid compositions and C-isotope signature. Org Geochem 35: 1371-1393

Wiesenberg GLB, Schwark L, Schmidt MWI (2006) Extractable lipids and colour in particle-size fractions and bulk arable soils. Eur J Soil Sci 57:634-643

Wiesenberg GLB, Lehndorff E, Schwark L (2009) Thermal degradation of rye and maize straw: lipid pattern changes as a function of temperature. Org Geochem 40: $167-174$

Wiesenberg GLB, Gocke M, Kuzyakov Y (2010) Incorporation of root-derived lipids and fatty acids in soil-evidence from a short term multiple $14 \mathrm{CO}_{2}$ pulse labelling experiment. Org Geochem 41:1049-1055

Wright VP, Platt NH, Wimbledon WA (1988) Biogenic laminar calcretes: evidence of calcified root-mat horizons in paleosols. Sedimentology 35:603-620

Xie S, Chen F, Wang Z, Wang H, Gu Y, Huang Y (2003) Lipid distribution in loess-paleosol sequences from northwest China. Org Geochem 34:1071-1079

Xie S, Guo J, Huang J, Chen F, Wang H, Farrimond P (2004) Restricted utility of $\delta^{13} \mathrm{C}$ of bulk organic matter as a record of paleovegetation in some loess-paleosol sequences in the Chinese Loess Plateau. Quat Res 62:86-93

Zech M, Buggle B, Leiber K, Marković S, Glaser B, Hambach U, Huwe B, Stevens T, Sümegi P, Wiesenberg GLB, Zöller L (2009) Reconstructing Quaternary vegetation history in the Carpathian Basin, SE Europe, using $n$-alkane 
biomarkers as molecular fossils: problems and possible solutions, potential and limitations. Quat Sci J 58:148-155

Zhou W, Xie S, Meyers PA, Zheng Y (2005) Reconstruction of late glacial and Holocene climate evolution in southern China from geolipids and pollen in the Dignan peat sequence. Org Geochem 36:1272-1284
Ziehen W (1980) Forschung über Osteokollen I. Mainzer Naturwiss Arch 18:1-70

Zöller L, Stremme H, Wagner GA (1988) ThermolumineszenzDatierung an Löss-Paläoboden-Sequenzen von Nieder-, Mittel und Oberrhein. Chem Geol 73:39-62 